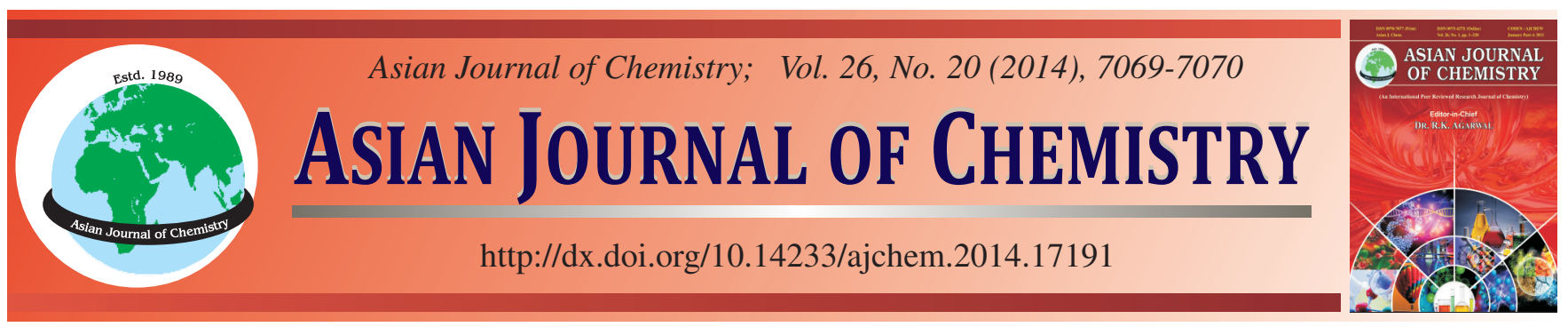

NOTE

\title{
Synthesis and Characterization of Zinc Oxide Nanoparticles by Modified Sol-Gel Method
}

Jamshid Khan $^{1}$, Habibnasir ${ }^{1}$, Sumera Mahboob ${ }^{2}$, Mohammed A.T. Abdel-ReheEm $^{3,4}$, Sharifullah $^{1}$, Riaz Ullah $^{5, *}$, IQbal Hussain ${ }^{6}$ and SAJJAD Haider ${ }^{7}$

\author{
${ }^{1}$ School of Chemical and Material Engineering, National University of Sciences and Technology, Islamabad, Pakistan \\ ${ }^{2}$ Center of Excellence in Science and Applied Technologies, Islamabad, Pakistan \\ ${ }^{3}$ Research Center, College of Science, King Saud University, Riyadh, Saudi Arabia \\ ${ }^{4}$ Biochemistry Department, Faculty of Agric. Ain Shams University, Cairo, Egypt \\ ${ }^{5}$ Department of Chemistry Government College, Ara Khel F.R, Kohat, Pakistan \\ ${ }^{6}$ Department of Chemistry, Islamia College, Peshawar, KPK, Pakistan \\ ${ }^{7}$ Department of Chemical Engineering, College of Engineering, King Saud University, Riyadh, Saudi Arabia
}

*Corresponding author: Fax: +92 51 9281314; Tel; +92 51 9060273; E-mail: afridiriaz@yahoo.com

\begin{abstract}
In the present work a modified sol-gel method is used for the synthesis of $\mathrm{ZnO}$ nano particles using zinc acetate dihydrate, ethylene diaminedihydrochloride and $\mathrm{NaOH}$ as precursors and poly(vinyl pyrrolidone) as surfactant to control the morphology and shape of synthesized $\mathrm{ZnO}$ nanoparticles. Poly(vinyl pyrrolidone) are used as capping agent and distilled water as solvent, using magnetic stirrer. The synthesized $\mathrm{ZnO}$ nano particles are dried in oven at $100{ }^{\circ} \mathrm{C}$ for $2 \mathrm{~h}$ and then calcinated at $500{ }^{\circ} \mathrm{C}$ in muffle furnace for $2 \mathrm{~h}$. The synthesized nanoparticles were characterized by using X-ray diffraction, scanning electron microscopy, energy dispersive X-ray spectra and Fourier transform infrared spectroscopy.
\end{abstract}

Keywords: ZnO, Sol-gel method, Nanoparticles, X-ray diffraction, Scanning electron microscopy, TGA, FTIR.

ᄂ - - - - - - - - - - - - - - - - - - - - - - - - - - - -

In the present era synthesis of nano-material with specific size and morphology has gained importance due to its use in various fields. Zinc oxide is $n$-type semiconductor and has direct wide band gap of $3.37 \mathrm{ev}$ and large exciton binding energy of $60 \mathrm{mev}$ at room temperature ${ }^{1,2}$. It is used in gas sensors, near UV emission, piezoelectric application and transparent conductor ${ }^{3-5}$. It is widely used in solar cells, luminescent material, electrical and acoustic devices, gas and chemical sensors, coatings material, as catalysts, in micro lasers, memory arrays and biomedical applications ${ }^{6-8}$. Various methods are used for the synthesis of $\mathrm{ZnO}$ nano particles like solid state reaction ${ }^{9,10}$, hydro thermal ${ }^{11}$, son chemical assisted ${ }^{12}$, micro wave assisted combustion ${ }^{13}$ and by polyol synthesis ${ }^{14}$. Sol-gel method ${ }^{15-17}$. In the present work $\mathrm{ZnO}$ nano particles has been synthesized through modified sol-gel process, using zinc acetate dihydrate, ethylene diaminedihydrochloride as precursors. Sol-gel is easy and low cost method.

The precursors used for the synthesis of $\mathrm{ZnO}$ nanoparticles is zinc acetate dihydrate, sodium hydroxide, poly(vinyl pyrrolidone), ethylene diaminedihydrochloride. Dissolve $5.39 \mathrm{~g}$ of zinc acetate in $50 \mathrm{~mL}$ distill water and stir on magnetis stirrer at
$700 \mathrm{rpm}$ for $20 \mathrm{~min}$, in second beaker dissolve $2 \mathrm{~g}$ of ethylene diaminedihydrochloride in $50 \mathrm{~mL}$ distil water and stir on magnetic stirrer for $20 \mathrm{~min}$ and also dissolve $1 \mathrm{~g}$ of sodium hydroxide and $1 \mathrm{~g}$ poly(vinyl pyrrolidone) in $50 \mathrm{~mL}$ distilled water. Now mix $50 \mathrm{~mL}$ of zinc acetate solution, $30 \mathrm{~mL}$ of ethylene diaminedihydrochloride in $1000 \mathrm{~mL}$ beaker, with drop wise addition of $\mathrm{NaOH}$ solution $(30 \mathrm{~mL})$ and also add $20 \mathrm{~mL}$ of PVP and stir on magnetic stirrer at $120{ }^{\circ} \mathrm{C}$ for $20 \mathrm{~min}$ at $500 \mathrm{rpm}$. White ppt obtained is left for $0.5 \mathrm{~h}$; filter and wash with distilled water for 5-6 times. Dry in oven at $100{ }^{\circ} \mathrm{C}$ for $2 \mathrm{~h}$, now ground it in pestle $\&$ mortar using agate pestle and mortar and calcinated at $500{ }^{\circ} \mathrm{C}$ in muffle furnace for $2 \mathrm{~h}^{15-17}$, process given in Scheme-I.

Zinc oxide nano particles have been synthesized through modified sol-gelprocess ${ }^{16}$ and were characterized by X-Ray diffraction technique as shown in Fig. 1. XRD data of synthesized material is matched with refrence 00-001-1136 which confirm zincite phase of the synthesized material.

SEM micrograph of the synthesized material shows spherical morphology and particles size ranges from 40-60 $\mathrm{nm}$. EDX spectra shows metal to oxygen ratio is $52: 47$ and in pure form (Fig. 2). 
(1) $\mathrm{Zn}\left(\mathrm{CH}_{3} \mathrm{COO}\right)_{2} \cdot 2 \mathrm{H}_{2} \mathrm{O}+\left[\mathrm{NH}_{2}-\mathrm{CH}_{2}-\mathrm{CH}_{2}-\mathrm{NH}_{2}\right] \cdot 2 \mathrm{HCl}$

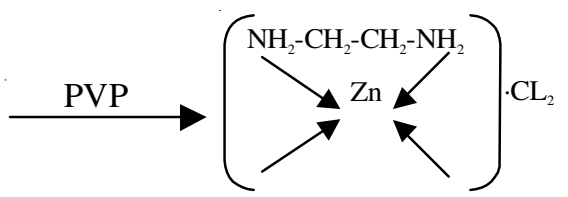

(2) $2 \mathrm{NaOH}+$ zinc complex Stirr at $120^{\circ} \mathrm{C}$ for $20 \mathrm{~min}$ $2 \mathrm{NaCl}+\mathrm{Zn}(\mathrm{OH})_{2}+\mathrm{NH}_{2}-\mathrm{CH}_{2}-\mathrm{CH}_{2}-\mathrm{NH}_{2}$

(3) $\mathrm{Zn}(\mathrm{OH})_{2} \stackrel{\left.\text { (Heat in oven at } 10{ }^{\circ} \mathrm{C} \text { for }\right) 2 \mathrm{~h}}{\longrightarrow} \mathrm{ZnO}+\mathrm{H}_{2} \mathrm{O}$

(4) $2 \mathrm{NaCl}+\mathrm{Zn}(\mathrm{OH})_{2}+\mathrm{NH}_{2}-\mathrm{CH}_{2}-\mathrm{CH}_{2}-\mathrm{NH}_{2}$ $\stackrel{\text { Calcinated at } 600{ }^{\circ} \mathrm{C}}{\longrightarrow} \mathrm{ZnO}$

Scheme-I: Synthesis of $\mathrm{ZnO}$ nanoparticles

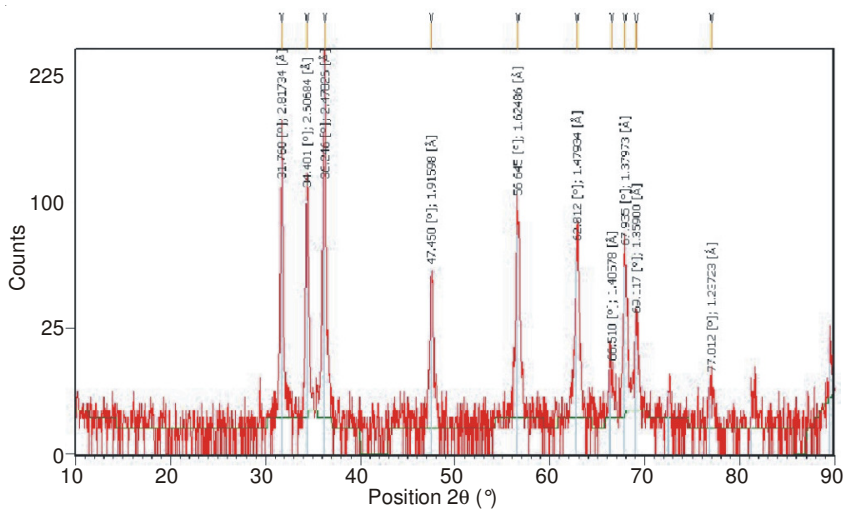

Fig. 1. X-ray diffraction pattern of synthesized $\mathrm{ZnO}$ nanomaterial
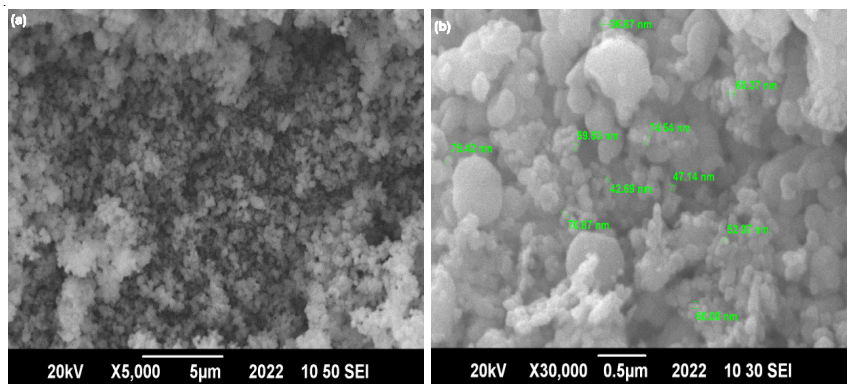

Fig. 2. SEM micrograph of synthesized $\mathrm{ZnO}$ nanoparticles (a) and (b)

EDX spectra of synthesized material shows that synthesized material is pure with no impurities and their metal to oxygen ratio is $52: 47$ (Fig. 3 ).

\section{Conclusion}

Zinc oxide nanoparticles were synthesized by modified sol-gel process by keeping proper stirring and temperature of the mixture. XRD result of the synthesized material shows

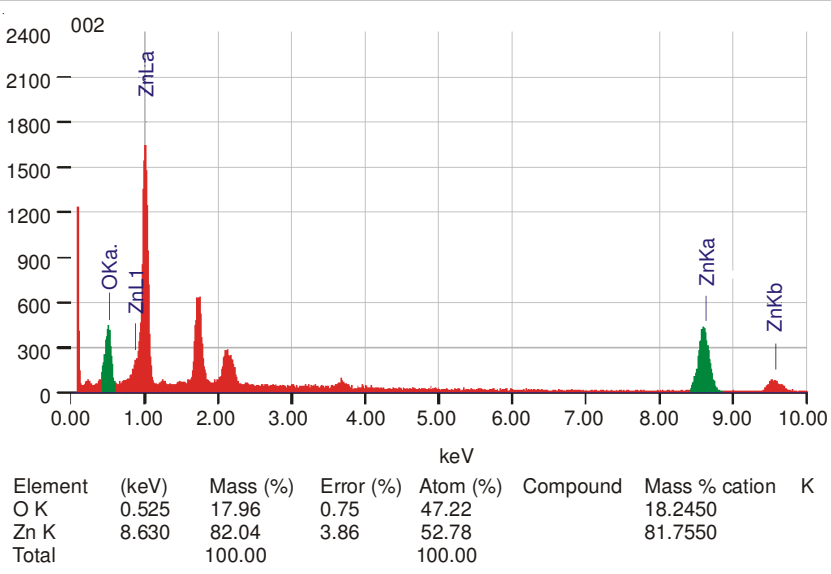

Fig. 3. EDX spectrum and list of elements present in the sample

hexagonal phase formation and SEM micrograph shows that the particles are spherical in shape and their size ranges from $40-60 \mathrm{~nm}$. EDX of synthesized zinc oxide nanoparticles shows metal to oxygen ratio is $52: 47$ and in pure form with no impurities.

\section{ACKNOWLEDGEMENTS}

This project was supported by King Saud University, Deanship of Scientific Research, College of Science Research Center.

\section{REFERENCES}

1. G.-C. Yi, C. Wang and W.I. Park, Semicond. Sci. Technol., 20, 22 (2005).

2. Q. Zhang, K. Yu, W. Bai, Q. Wang, F. Xu, Z. Zhu, N. Dai and Y. Sun, Mater. Lett., 61, 3890 (2007).

3. Y. Lv, L. Guo, H. Xu, L. Ding, C. Yang, J. Wang, W. Ge, S. Yang and Z. Wu, J. Appl. Phys., 99, 114302 (2006).

4. A. Hachigo, H. Nakahata, K. Higaki, S. Fujii and S.I. Shikata, Appl. Phys. Lett., 65, 2556 (1994).

5. L. Spanhel and M.A. Anderson, J. Am. Chem. Soc., 113, 2826 (1991).

6. S. Kunjara Na Ayudhya, P. Tonto, O. Mekasuwandumrong, V. Pavarajarn and P. Praserthdam, Cryst. Growth Des., 6, 2446 (2006).

7. M. Vafaee and M.S. Ghamsari, Mater. Lett., 61, 3265 (2007).

8. Y.S. Kim, W.P. Tai and S.J. Shu, Thin Solid Films, 491, 153 (2005).

9. C. Feldmann and H. Jungk, Angew. Chem. Int. Ed., 40, 359 (2001).

10. C.Y. Lee, T.Y. Tseng, S.Y. Li and P. Lin, J. Appl. Phys., 99, 24303 (2006).

11. L. Poul, S. Ammar, N. Jouini, F. Fievet and F. Villain, Solid State Sci., 3, 31 (2001).

12. K.S. Suslick, Science, 247, 1439 (1990).

13. C. Feldmann and H.-O. Jungk, Angew. Chem. Int. Ed., 40, 359 (2001).

14. L. Poul, S. Ammar, N. Jouini, F. Fievet and F. Villain, Solid State Sci., 3, 31 (2001).

15. R.C. Perez, O.J. Sandoval, J.M. Marin, A.M. Galvan and G.T. Delagado, Sci. Technol., 17, 1816 (1999).

16. H. Li, J. Wang, H. Liu, H. Zhang and X. Li, J. Cryst. Growth, 275, 943 (2005).

17. X.L. Cheng, H. Zhao, L.H. Huo, S. Gao and J.G. Zhao, Sens. Actuators $B, 102,248$ (2004). 